\title{
The Effect of Vulcanized Tire Waste on Mechanical Properties of Rubber Concrete as Construction Materials
}

\author{
Edward Ngii ${ }^{1}$, Rini Sriyani ${ }^{2}$, Muh. Hasbi ${ }^{3}$, Muhlis Serah ${ }^{4}$ \\ \{edward.ngii@uho.ac.id ${ }^{1}$, rinisriyani.uho@gmail.com ${ }^{2}$, hasbi@gmail.com ${ }^{3}$ \} \\ 1,2,3,4 Faculty of Engineering, Halu Oleo University, Bumi Hijau Campuss, \\ H.E.A. Mokodompit Street, Andonohu, Kendari, 93232, Indonesia
}

\begin{abstract}
The growing amount of rubber-shredded waste from tires causes environmental problems. This research aimed to analyze the application of shredded rubber in the concrete mixtures. Laboratory tests were carried out on 15 cylinders and 15 beams of concrete specimens that contained shredded rubber. Compressive strength, flexural strength, and modulus of elasticity measurements were performed using test specimen containing $400 \mathrm{~kg} / \mathrm{m}^{3}$ of cement and varied volume ratio of shredded rubber to sand which were $0 \%$ : $100 \% ; 10 \%: 90 \% ; 20 \%: 80 \% ; 30 \%$ : $70 \%$; and $40 \%: 60 \%$. The results show that the mechanical properties of concrete decreased by $50 \%$ after the addition of shredded rubber in the mix by $40 \%$. However, the same volumetric ratio of sand and shredded rubber increased the concrete ductility. The use of $20 \%$ shredded rubber in the concrete mix can produce light weight concrete for structural construction.
\end{abstract}

Keywords: Concrete, Rubber, Waste, Cement, Mechanical.

\section{Introduction}

Concrete technology is developed continuously in order to have better properties. One of the demands is how to reduce the relatively high weight of concrete units and improve brittle concrete properties. Rubber is known as a lightweight material and has a high ductility that is resistant to deformation.

The use of rubber in concrete mixes was carried out by [1] which concluded that rubber concrete has limited application due to its low mechanical properties, but has several properties needed such as lower density, higher toughness, higher impact resistance, enhance ductility, more efficient sound and heat insulation compared to conventional concrete. This is in line with [2] which shows an increase in the value of concrete ductalities due to the addition of rubber in the concrete mixture. Wider use has also been recommended for flexible subbase applications in pavements [1] or as concrete pavements [3].

The wider use of rubber is because it is supported by the potential of rubber waste every year. [2] reports that in Germany more than 600,000 tons of used tires are disposed of annually while in America similar dumps also occur annually with a total tire of more than $279,000,000$ units. In Indonesia there is still no record of how much used tires are dumped for each year, but the 2010 APBI sales data report shows the figure of 41,000,000 units. Thus, the waste of unused rubber tires is increasingly increasing. This problem is getting bigger because the tires cannot decompose easily if they are left alone. Therefore, efforts are needed to process the tire rubber waste as a construction material. The purpose of this study was to 
determine the characteristics of compressive strength, flexural strength and elastic modulus of rubber concrete on the use of portland cement $400 \mathrm{~kg} / \mathrm{cm} 3$.

\subsection{Experimental Program \\ 1.1.1 Materials}

The rubber concretemixed material in this study consisted of type I portland cement (specific gravity 3.15), natural sand from ex. Merapi (specific gravity 2.740) with fineness modulus of 3.026 and unit weight of $1571 \mathrm{~kg} / \mathrm{m}^{3}$, shredded rubber (specific gravity 1.137) is less than $4.75 \mathrm{~mm}$ (passing the No.4 sieve) from vulcanized industry and unit weight of 451 $\mathrm{kg} / \mathrm{m}^{3}$. The water used is PDAM water available in the laboratory.

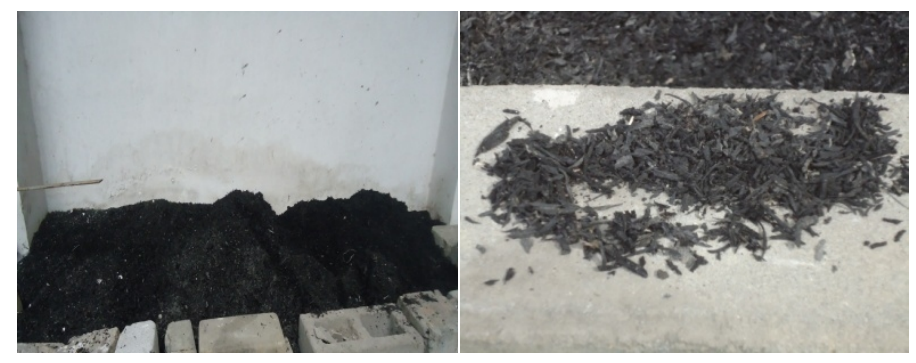

Fig. 1. Shredded rubber from vulcanized tire industry

\subsubsection{Mix Design}

The rubber concrete mixture design refers to [4] with the required mortar consistency value of $70-115 \%$. Rubber concrete was designed by cement content of $400 \mathrm{~kg} / \mathrm{m}^{3}$ with variations of rubber shavings to sand at $0 \%, 10 \%, 20 \%, 30 \%$ and $40 \%$. The mixture composition shown refers to Table 1.

Table 1. Material composition of rubbercrete.

\begin{tabular}{cccccccc}
\hline $\begin{array}{c}\text { Number of } \\
\text { variation }\end{array}$ & $\begin{array}{c}\text { Rubber } \\
(\%)\end{array}$ & $\begin{array}{c}\text { Sand } \\
(\%)\end{array}$ & $\begin{array}{c}\text { Water } \\
\text { cement } \\
\text { ratio (fas) }\end{array}$ & $\begin{array}{c}\text { Cement } \\
(\mathrm{kg} / \mathrm{m} 3)\end{array}$ & $\begin{array}{c}\text { Water } \\
(\mathrm{kg} / \mathrm{m} 3)\end{array}$ & $\begin{array}{c}\text { Rubber } \\
(\mathrm{kg} / \mathrm{m} 3)\end{array}$ & $\begin{array}{c}\text { Sand } \\
(\mathrm{kg} / \mathrm{m} 3)\end{array}$ \\
\hline Variasi 1 & 40 & 60 & 0,57 & 400 & 228 & 180,40 & 942,60 \\
Variasi 2 & 30 & 70 & 0,58 & 400 & 232 & 135,30 & 1099,70 \\
Variasi 3 & 20 & 80 & 0,59 & 400 & 236 & 90,20 & 1256,80 \\
Variasi 4 & 10 & 90 & 0,61 & 400 & 244 & 45,10 & 1413,90 \\
Variasi 5 & 0 & 100 & 0,63 & 400 & 252 & 0,00 & 1571,00 \\
\hline
\end{tabular}

\subsubsection{Samples}

Each variation of the mixture was made by specimens 3 compressive test objects so that the total test specimens were 30 pieces. Press specimens in the form of a cylinder size of $150 \times$ $300 \mathrm{~mm}$ while a flexible test object in the form of a block size $600 \times 150 \times 150 \mathrm{~mm}$. The composition of the material refers to Table 1 , which is adjusted for the volume of test material needed. During mixing, control of scattered values is done so that it approaches the results obtained in Table 2. Measurement of specific gravity of fresh concrete for each specimen is 
carried out to ensure the proportion of material is in accordance with the planning results such as Table 3 . Next the test object is treated until age 28 before testing and flexible.

\subsubsection{Setup Testing}

The implementation of the compressive test was carried out after the concrete was 28 days old. Compressive strength test with modulus is carried out according to SNI standard [5]. The beam flexural strength test was carried out by means of third point loading according to standard [6]. Observations were made on stress, strain, and peak load which caused the test specimen to be damaged.

\subsubsection{Analysis}

Analysis of the concrete cylinder compressive strength is calculated by equation (1) while the flexural strength is calculated by equation (2) as follow:

$$
\begin{aligned}
& f_{c}=P /\left(0.25 \pi \mathrm{d}^{2}\right) . \\
& f_{r}=P L /\left(b h^{2}\right) .
\end{aligned}
$$

Where $f_{c}$ is compressive strength; $f_{r}$ is flexural strength; $P$ is maximum load; $L$ is distance of tumpuan; $d$ is diameter of silinder; $b$ is wide of beam; $h$ is height of beam.

The modulus of elasticity of rubber concrete was analyzed using two equations namely equation (3) referring to the empirical equation in [7] and equation (4) based on the results of stress-strain readings on the test object:

$$
\begin{aligned}
& E_{c}=0.043\left(\mathrm{w}_{c}\right)^{1.5} \sqrt{ }\left(f_{c}\right) . \\
& E_{c s}=0.40 f_{2} /\left(\varepsilon_{2(0,4)}\right) .
\end{aligned}
$$

Where Ec is elasticity modulus of concrete (MPa); Ecs is a modulus elasticity (MPa); wc is weigth of concrete $(\mathrm{kg} / \mathrm{m} 3) ; 0.40 \mathrm{f}_{2}$ is the concrete compressive stress at $40 \%$ loading failure (MPa); $\varepsilon_{2}(0.4)$ is a strain on concrete when the concrete stress reaches $0.40 \mathrm{f}_{2}$.

\section{Results and Discussion}

\subsection{Rubbercrete Weight}

The results of concrete weighing are presented in Table 2.

Table 2. Weight of rubbercrete after 28 days curring.

\begin{tabular}{cccc}
\hline $\begin{array}{l}\text { Number of } \\
\text { variation }\end{array}$ & $\begin{array}{c}\text { Rubber } \\
(\%)\end{array}$ & $\begin{array}{c}\text { Sand } \\
(\%)\end{array}$ & $\begin{array}{c}\text { Weight of } \\
\text { concrete }(\mathrm{kg})\end{array}$ \\
\hline 1 & 0 & 100 & 2108,58 \\
2 & 10 & 90 & 1999,59 \\
3 & 20 & 80 & 1955,41 \\
4 & 30 & 70 & 1870,36 \\
5 & 40 & 60 & 1803,19 \\
\hline
\end{tabular}


Table 2 shows that the more the amount of rubber in the concrete mixture, the weight of the concrete decreases. The amount of the decrease in concrete weight is $3.5-14.5 \%$. Referring to the weight of concrete following the standards [8], the design of rubber concrete with the amount of cement $400 \mathrm{~kg} / \mathrm{m} 3$, shows the condition as structural concrete up to the use of rubber $30 \%$, but in the use of rubber $40 \%$, rubber concrete mixture has shown behavior as a light weight concrete structure.

\subsection{Compressive Strength of Rubbercrete}

The results of the compressive strength test at the age of 28 days are presented in Table 3 below:

Table 3. Compressive strength of rubbercret after 28 days curring.

\begin{tabular}{cccc}
\hline $\begin{array}{c}\text { Number of } \\
\text { variation }\end{array}$ & $\begin{array}{c}\text { Rubber } \\
(\%)\end{array}$ & Sand (\%) & $\begin{array}{c}\text { Compressive } \\
\text { strength (MPa) }\end{array}$ \\
\hline 1 & 0 & 100 & 23,327 \\
2 & 10 & 90 & 21,513 \\
3 & 20 & 80 & 16,538 \\
4 & 30 & 70 & 11,041 \\
5 & 40 & 60 & 10,097 \\
\hline
\end{tabular}

Table 3 shows that the greater the use of rubber, the compressive strength of concrete decreases. The decline reached $29 \%$ in the use of rubber $20 \%$ and reached $57 \%$ due to the use of $40 \%$ rubber in concrete mixes. This decrease in compressive strength will affect the use of rubber concrete in construction based on the criteria of [8] as shown in Figure 1.

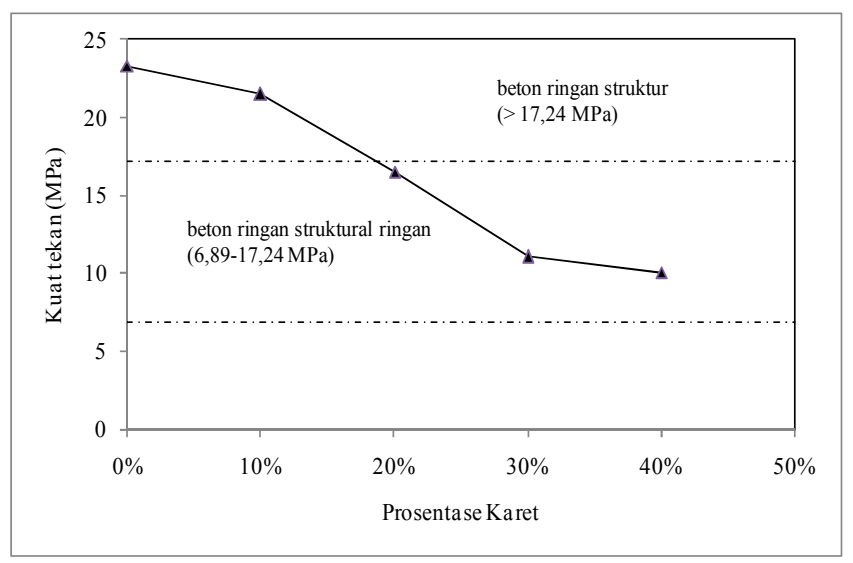

Fig. 1. Relationship between the rubber concentration and concrete compressive strength based on SNI 03-3449-1994.

Figure 1 shows that for structural purposes, rubber concentration should be limited to a maximum of $20 \%$. The use of rubber between $20-40 \%$ should only be used for lightweight structures. 


\subsection{Flexural strength of Rubbercrete}

The results of the flexural strength test at the age of 28 days are presented in Table 3.

Table 4. Flexural strength of rubbercrete after 28 days curing.

\begin{tabular}{cccc}
\hline $\begin{array}{c}\text { Number of } \\
\text { variation }\end{array}$ & $\begin{array}{c}\text { Rubber } \\
(\%)\end{array}$ & $\begin{array}{c}\text { Sand } \\
(\%)\end{array}$ & $\begin{array}{c}\text { Flexural } \\
\text { strength (MPa) }\end{array}$ \\
\hline 1 & 0 & 100 & 2,421 \\
2 & 10 & 90 & 2,385 \\
3 & 20 & 80 & 1,869 \\
4 & 30 & 70 & 1,616 \\
5 & 40 & 60 & 1,191 \\
\hline
\end{tabular}

Table 4 shows that the flexural strength of the beam has decreased with the increase in the percentage of rubber. At $10 \%$ rubber content, the reduction in flexural strength was only $1.9 \%$ but in rubber use $40 \%$, the flexural strength decreased by $50.82 \%$.

\subsection{Relationship between Compressive and Flexural Strength}

The relationship between the compressive and flexural strength of the concrete is shown through the equations of [9], as displayed in Table 5.

Table 5. Comparison of compressive and flexural strength of rubbercrete.

\begin{tabular}{ccccccc}
\hline \multirow{2}{*}{$\begin{array}{c}\text { Number of } \\
\text { variation }\end{array}$} & $\begin{array}{c}\text { Rubber } \\
(\%)\end{array}$ & $\begin{array}{c}\text { Sand } \\
(\%)\end{array}$ & $\begin{array}{c}\text { Compressive } \\
\text { strength }\left(f_{c}\right)\end{array}$ & $\begin{array}{c}\text { Compressive } \\
\text { strength }\left(f_{c}\right)\end{array}$ & $\begin{array}{c}\text { Lightweight } \\
\text { concrete } \\
(\mathrm{MPa})\end{array}$ & $\begin{array}{c}\text { Total lightweight } \\
\text { concrete }\end{array}$ \\
\hline 1 & 0 & 100 & 23,327 & 23,327 & 3.381 & 2.536 \\
2 & 10 & 90 & 21,513 & 21,513 & 3.247 & 2.435 \\
3 & 20 & 80 & 16,538 & 16,538 & 2.847 & 2.135 \\
4 & 30 & 70 & 11,041 & 11,041 & 2.326 & 1.744 \\
5 & 40 & 60 & 10,097 & 10,097 & 2.224 & 1.668 \\
\hline
\end{tabular}

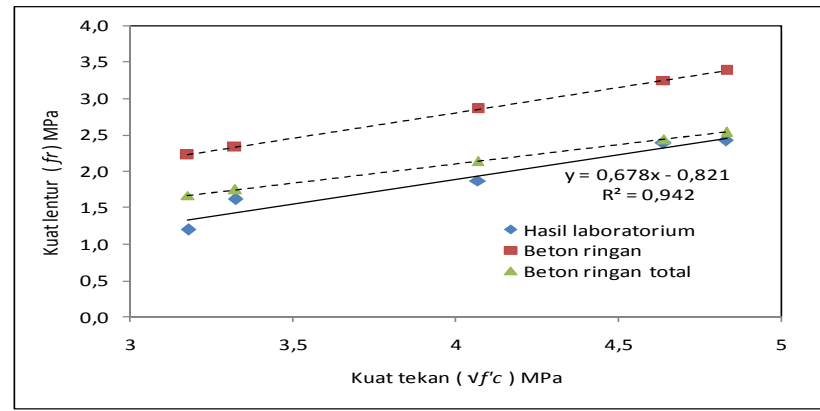

Fig. 2. Relationship of compressive and flexural strength of 28-days rubbercrete.

Figure 2 shows that the addition of rubber is more influential in decreasing the compressive strength of concrete compared to its flexural strength at the same concrete age (28 days). The results of laboratory tests show that rubber concrete approached behavior as total lightweight concrete based on the equation in [9]. From the evaluation of the relationship 
between compressive strength and flexural strength of rubber concrete, the following equation is obtained:

$$
f_{r}=0.678 \sqrt{ }\left(f_{c}\right)-0.821
$$

\subsection{Elastic Modulus of Rubbercrete}

The elastic modulus of rubber concrete was analyzed from the results of reading the stress-strain curve in the laboratory and the empirical formula following [9]. The modulus of elasticity obtained is listed in Table 6.

Table 6. Elastic modulus of rubbercrete.

\begin{tabular}{|c|c|c|c|c|c|c|c|}
\hline \multirow{2}{*}{$\begin{array}{l}\text { Number of } \\
\text { variation }\end{array}$} & \multirow{2}{*}{$\begin{array}{c}\text { Rubber } \\
(\%)\end{array}$} & \multirow{2}{*}{$\begin{array}{l}\text { Sand } \\
(\%)\end{array}$} & \multirow{2}{*}{$\begin{array}{l}\text { Laboratory Test } \\
\text { result } E_{\text {lab }}(\mathrm{MPa})\end{array}$} & \multicolumn{2}{|c|}{ SNI T-15-191-03 } & \multicolumn{2}{|c|}{ Nilai banding } \\
\hline & & & & $E_{l}(\mathrm{MPa})$ & $E_{2}(\mathrm{MPa})$ & $E_{\text {lab }} / E_{l}$ & $E_{l a b} / E_{l}$ \\
\hline 1 & 0 & 100 & 19721.33 & 20108.65 & 22700.11 & 0.981 & 0.869 \\
\hline 2 & 10 & 90 & 18899.67 & 17833.25 & 21799.57 & 1.060 & 0.867 \\
\hline 3 & 20 & 80 & 12742.00 & 15120.47 & 19113.42 & 0.843 & 0.667 \\
\hline 4 & 30 & 70 & 10523.33 & 11557.52 & 15617.37 & 0.911 & 0.6674 \\
\hline 5 & 40 & 60 & 8754.67 & 10462.15 & 14934.41 & 0.837 & 0.586 \\
\hline
\end{tabular}

Table 6 shows a decrease in concrete stiffness due to the addition of rubber in the mixture. The use of $10 \%$ shaved rubber will reduce the modulus of elasticity by $4.17 \%$ and the addition of shaved rubber to $40 \%$ has reduced the modulus of elasticity by $55.61 \%$. The comparative value of the elastic modulus that approaches 1 is the appeal value (Elab/E1), so the calculation of the elastic modulus of rubber concrete based on compressive strength data can use equation (3).

\section{Conclusion}

The conclusions of this study are as follows.

1) $40 \%$ use of shredded rubber reduced compressive strength, flexural strength, and elastic modulus of rubber concrete with a percentage decrease and the value obtained is $57 \%$ (10.09 $\mathrm{MPa}), 50.82 \%(2.421 \mathrm{MPa})$ and 55.61 respectively. \% $(8754.67 \mathrm{MPa})$.

2) The use of rubber concrete for structural purposes should be limited to $20 \%$ use of shredded rubber, while concentration higher than $20 \%$ should only be used for light structures.

\section{References}

[1] Nehdi, M. dan Khan, A.: Cementitious Composites Containing Recycled Tire Rubber. An Overview of Engineering Properties and Potential Applications, Cement, Concrete, and Aggregates Journal. CCAGDP, No. 1, Vol. 23, pp. 3-10, 2001.

[2] Satyarno: Penggunaan Serutan Karet Ban Bekas Untuk Campuran Beton. Jurnal Media Teknik, No. 4, Vol. XXVIII, pp. 45-51, 2006.

[3] Hernandez-Olivares, F., Barluenga, G., Parga-Landa, B., Bollati, M., Witoszek, B.: Fatique behaviour of Recycled Tyre Rubber-Filled Concrete and its Implications in The 
Design of Rigid Pavements, Journal of Construction and Building Materials, No. 21, pp. 1918-1927, 2006.

[4] ASTM C270-57T. Standard Specification for Mortar for Unit Masonry.

[5] SNI 1974:2011. Cara Uji Kuat Tekan Beton dengan Benda Uji Silinder, 2011.

[6] SNI 4431-2011. Cara Uji Kuat Lentur Beton Normal dengan Dua Titik Pembebanan, 2011.

[7] SNI 03-2874-2002. Tata Cara Perencanaan Struktur Beton untuk Bangunan Gedung, 2002.

[8] SNI 03-3449-1994. Tata Cara Rencana Pembuatan Campuran Beton Ringan, 1994.

[9] SNI T-15-1991-03. Tata Cara Perhitungan Struktur Beton untuk Bangunan Gedung, 1991. 